\title{
THE MANAGEMENT STRATEGY OF HEADMASTER IN EFFORTS TO INCREASE SELF AWARENESS OF SCHOOL RESIDENTS OF THE IMPORTANCE ENVIRONMENT
}

\author{
Friska Fitriani Sholekah $^{\text {a*, Fitri Nur Mahmudah }}{ }^{\mathrm{b}}$ \\ Magister Manajemen Pendidikan \\ Universitas Ahmad Dahlan
}

Daerah Istimewa Yogyakarta, Indonesia Friskafitriani16@gmail.com, fnurmahmudah@gmail.com

\begin{abstract}
The research aims to discuss(1) How planned of the headmaster in an effort to increase self-awareness of school residents regarding the importance of the environment, 2) How to implement planned programs related to efforts to increase self-awareness of school residents, and 3) identify supporting factors in implementation of the program carried out as an effort to increase self-awareness of school residents. The method of research used qualitative method. Subjects of this research consisted of headmaster, subject teachers, and students. Subjects of research is based on determining purposive random sampling technique. Collecting of data is through interviews, observation and documentation. The analyzing of data using the Miles \& Huberman analysis model with the several stages are collecting of data, data reduction, data presentation and drawing conclusions. The results show that there an increased in self-awareness of school residents about the environment after several programs had been carried out. The vision, mission and regulation of the school are being the one of programs that succeeded in increase awareness of school residents. The implementation program by applying clean fridays, installing CCTVs and coaching by the headmaster and teachers to the students directly. The supporting factors in implementation of efforts to increase self-awareness of school residents to the environment are the commitment, awareness and desire of school residents to embody the programs that have been implemented. The strategy of headmaster is always monitor the activities of school residents through the CCTVs that have been installed and spot checking directly to be more effective and the results showed increased self-awareness of school residents for enviroment has occurred since last semester.
\end{abstract}

Keywords: headmaster, self-awareness, strategy and the enviroment.

Received: 21 Jan 2020 - Revised: 22 Feb 2020 - Accepted 19 March 2020 - Available online 30 June 2020

\section{INTRODUCTION}

Nowadays, environmental problems have developed into the subject of conversation not only in Indonesia but also at the World level. According to the statement made by Permana \& Ulfatin (2018:11) that the environment has begun to be threatened as a result of various impacts from human activities. The significant changes began shown from year to year. One of the changes in the increasingly extreme weather, resulting in drought. The young generation must have the responsibility and concern for the environment that is embedded from an early age through the education process so that they can change human behaviour in interacting with the environment. A solution is needed to overcome these problems as stated by Mardiana (2014:1) that there is a need for a form of education that focuses on the goal of growing individual awareness and concern for the environment. The young generation who have environmental awareness need to be grown from the family to the social environment. Schools in Poland have even implemented efforts to increase environmental awareness, which are implemented in the curriculum and integrated into various subjects. Schools in Poland have 
even implemented efforts to increase environmental awareness, which are implemented in the curriculum and integrated into various subjects.

Not much different from Poland, Israel is also implementing education to increase awareness of the environment. This was revealed in a study conducted by Potter (2015), it turns out that even though the program to increase environmental awareness has been implemented by the Israeli government, but the principal as one of the highest policymakers in schools must design effective programs to improve environmental awareness behaviour. The importance of the principal's role in determining strategies for implementing programs to improve environmental awareness behaviour must be fully realized. According to the statement made by Afriadi (2017:9) which states that the principal's leadership is considered important because with the leadership it will facilitate the process of supporting and influencing teachers to do various things that have been used as programs to increase self-awareness of the school members towards the environment.

Some researches about the leadership of school principals have been carried out including the leadership of school principals in the implementation of character education conducted by Afriadi (2017) at the Junior High School (SMP) in Sindue district with a total of 5 schools revealed that the character of students is influenced by the school environment and beyond, so there is a need for supervision from the principal to participate in improving character education in schools. Other research conducted by Suriansyah \& Aslamiah (2015) at the Integrated Islamic Elementary School (SDIT) Ukhuwah Islamiyah Banjarmasin. The research revealed that in shaping the character of students, a principal should implement exemplary strategies, discipline, instructional leadership and quality, as well as empowering all school members. The results of research conducted by Afriadi (2017) revealed that the teacher should apply the exemplary strategy, habituation, and touch their heart. Also, the parents and the school members should implement an effective communication and partnership strategy. The increased environmental awareness behaviour was also examined by Suriansyah \& Aslamiah (2015) conducted at PAUD AYO MAJU Arus Deras Village. The conclusion from the research that has been done is that the application of learning to clean the schoolyard for children can improve environmental awareness behaviour.

The study of the 3 kinds of research above has not yet seen the role of the Principal's Management Strategy in Efforts to Increase the Self-Awareness of School Members of the Importance of the Environment. The principal is considered as one of the important factors that determine success in implementing an education program. Principal's management strategies to increase self-awareness need to be investigated more deeply. This is a solution to overcome environmental problems. The lack of self-awareness of the environment needs to be overcome so that the damage caused by human actions does not increase.

The principal's management strategy as an effort to increase self-awareness of school members needs to be revealed so that it is expected to be able to be used as a reference for other school principals and education practitioners in implementing environmental education in their respective schools. The theoretical contribution of this research is expected to be able to add information for practice analysis or theory about the importance of the environment in secondary schools.

The writing of this article acknowledged several questions, including:

1) To what extent does the principal's management strategy play a role in increasing the self-awareness of the school members towards the environment?

2) What program is the most effective way to increase the awareness of the school members towards the environment? 


\section{METHODS}

The research method used is qualitative. Subjects studied consisted of the principal, school subjects' teachers, and students in SMP Muhammadiyah 2 Mlati. The determination of research subjects is based on a purposive random sampling technique. The data that has been collected is then analysed using the Miles \& Huberman analysis model with the stages carried out namely data collection, data reduction, data presentation and conclusions.

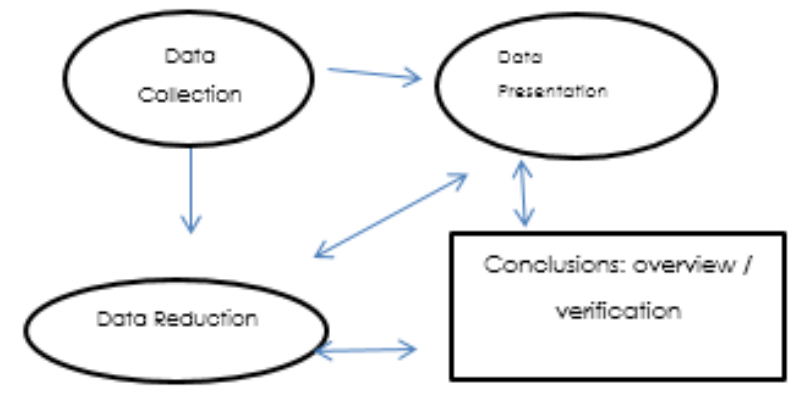

Image 1. Qualitative Research Data Analysis Process

The image shows the relationship between data collection and data analysis.

1) Data collection is the first step in data analysis activities. Data collection was done by conducting in-depth interviews. Interviews were conducted with several speakers including the following:

Table 1. List of Speakers

\begin{tabular}{cc}
\hline Namber & Posision \\
\hline 1 & headmaster \\
2 & Religion teacher \\
3 & The employee \\
4 & Female Student \\
5 & Male student \\
\hline
\end{tabular}

Interviews were conducted with the speakers of research consisting of the school principal, 1 religious subject teacher, 1 administrative staff and 2 students of SMP Muhammadiyah 2 Mlati. Interviews with school principal were carried out to obtain information about strategies and management to increase the awareness of school members about the environment. Through an interview with the religious subject teacher, we get the information about the implementation of school programs actualized by teachers both through learning and mentoring to school members related to increasing the awareness of the environment. Interviews conducted with students aimed to find out how their selfawareness of the environment after several programs carried out to increase the selfawareness of the environment. Documentation was also carried out to gather information relating to the vision and mission of the school, the school environment such as the situation of the classrooms, bathrooms and schoolyards.

1) The second step, after all the data collected from interviews and documentation, is data reduction. The information that has been obtained is then collected and combined so that it becomes a unity of information that can be linked. Choosing the information that can be used and unnecessary so that you get conclusions from the information that has been obtained.

2) Data presentation is then carried out to compile all information so that a conclusion can be drawn from the research conducted. This data presentation is done to find meaningful relationships and provide the possibility of concluding.

3) The conclusion is part of the data analysis activities. The conclusions were also verified during the study.

\section{RESULTS AND DISCUSSION}

\section{A. Results}

The results of this study explain the research questions that have been outlined previously.

\section{Principal's Management Strategy}

The principal's strategy to increase the awareness of the school members towards the environment can be seen from the vision and mission of the school. Establishing an

The Management Strategy of Headmaster in Efforts to Increase Self Awareness of School Residents of The Importance Environment| 64 
environmentally friendly Muslim is one of the things included in the vision of the school. Greening movement, saving energy including water and electricity also minding the waste are implementations of the vision and mission of the school. The role of a leader is very influential on the course of education with planning to program evaluation conducted. Educational success in schools according to Afriadi (2017:4) influenced by the principal's leadership in determining the planning up to the evaluation process. The vision and mission of the school become important because it contains the educational goals of the school to be achieved.

The vision and mission of the school which relates to the formation of Muslim people with environmental insight are implemented in several school programs such as greening, saving electricity and water.

\section{B. Discussion}

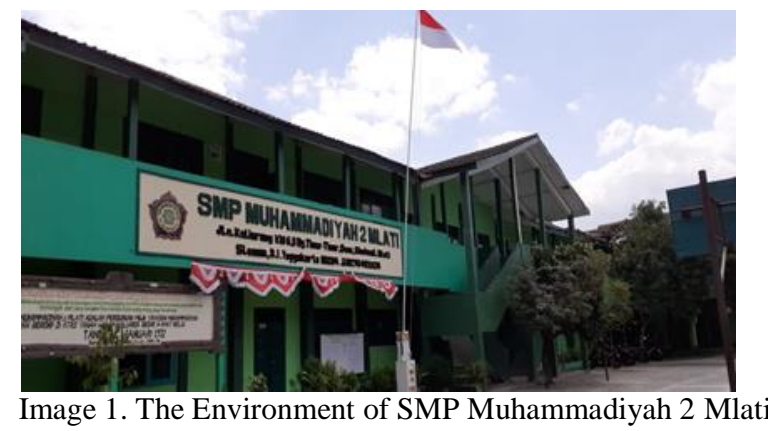

Based on the picture above, it can be seen that the environment of SMP Muhammadiyah 2 Mlati has started to be greened and structured. With a yard that is wide enough, we can look that there is a little scattered garbage. The picture was taken while the lesson is in progress and it appears that all students were sitting orderly in the classroom.

\section{Empowering the School Members}

The principal's strategy in addition to being listed in the vision and mission is to start empowering all school members, for example by directing subject teachers to incorporate environmental education into several subjects to deliver to the students. To nurture the awareness about the environment is not only done in Indonesia, the research conducted by Hadzigeorgiou \& Skoumios (2013:71) in Africa also pointed out about environmental concerns that being felt by the teachers, staffs and school volunteers in the Cape Town area so they began to build schools with better environmental assistance.

Activities related to environmental care are also carried out such as the provision of clean Fridays, mandatory to clean the classroom before leaving school and greening the school environment. A good principal's strategy according to Suriansyah \& Aslamiah (2015:245) can be used to improve character by empowering all school members.

Empowering school members by opening relationships between teachers and students to join together to increase awareness of the environment turns out to be effective and essential for continuing education according to Conde \& Samuel Sánchez (2010:490) that the school principal and school members must actively participate to foster environmental awareness behaviour. The success of environmental education to foster environmental awareness behaviour according to Daryanto (2013:24) can be determined, among other things, by the quality and quantity of school members such as school principal, teachers and staffs.

3. Increasing the awareness of the environment through learning in class

Increasing the awareness of the environment was done by applying it to several subjects listed in the curriculum. An interview conducted with one of the teachers revealed that incorporating environmental education into learning helped increase students' environmental awareness. Approach to subject matter according to research conducted by Treagust, Amarant, Chandrasegaran, \& Won (2016:5602) in Florida stated that it succeeded in increasing students' commitment to protecting the environment. 
The development of good methods to increase environmental awareness is considered good and one of the factors that determine the success of environmental education as an effort to increase awareness of the environment. This is supported by research conducted by Mardiana (2014:9-10) that to achieve the expected facilities, it is necessary to have a method which was done well so that the quality of environmental education can be improved. Research on inculcation of environmental awareness behaviour was also carried out in Finland by Hadzigeorgiou \& Skoumios (2013:181) where the results showed that vocational schools have begun to apply the integration of environmental education in the curriculum as continuing education.

\section{Installation of Surveillance Cameras}

Supervision through the installation of closedcircuit television (CCTV) around the school environment was carried out by the principal as one of the strategies to increase awareness of the environment. Interviews conducted with administrative staff said that this happened because of CCTV surveillance.

Since the installation was done up to now, the school can monitor some of the activities of students and school members. Activities carried out by school members can be recorded and if proven to do unnecessary actions such as littering, crossing walls, damaging the environment and going out during class time will get sanctions. The principal's strategy to install CCTV was quite successful and effective in avoiding environmentally damaging behaviour.

The surveillance camera is considered quite effective because it is a media that shows the real activities of school members. CCTV shows the actual time so according to Aulianida, Liestyasari, \& Ch (2019:16) surveillance using CCTV has the advantage because it shows the real-time so there will be no manipulation of the records obtained.

5. Effective Programs
School programs that are considered effective in increasing school community self-awareness towards the environment include the installation of CCTV in the school environment. With this installation, school members are wary and more careful about taking illegal actions such as littering, scribbling on walls, damaging plants and other environmentally unfriendly actions. Although initially forced over time it will become a habit familiarized by school members.

The inculcation of environmental education by several subject teachers such as religion and science proved effective for fostering students' environmental awareness behaviour. Research conducted by Hadzigeorgiou \& Skoumios (2013:421) also states that a strategy that might be used to protect

\section{CONCLUSION/RECOMENDATION}

The conclusion of the research conducted that the principal's strategy in an effort to increase the awareness of school members towards environmental awareness behaviour can be done through the vision and mission of the school by empowering all school members for example by organizing the greening program of the school, saving electricity and water and incorporating environmental material in curriculum. Programs such as CCTV installation, clean Friday, greening and environmental cleanliness were found to be effective in increasing the awareness of the school community towards the environment. The role of the principal in responding to problems at school is important. Achievement of school goals according to Aulianida et al (2019:149) can be done if the principal can develop strategies, supervise, develop and seek initiatives from existing problems and make good relations between school members.

\section{REFERENCES}

Afriadi, A. (2017). Peranan Kepala Sekolah Dalam Pelaksanaan Pendidikan Karakter Di Sekolah Menengah Pertama (Smp) Di Kecamatan Sindue. Katalogis, 5(1), 1-10. 
Aulianida, D., Liestyasari, S. I., \& Ch, S. R. (2019). 済 無 No Title No Title. Journal of Chemical Information and Modeling, 53(9), 1689-1699. https://doi.org/10.1017/CBO9781107415324.00 4

Conde, M. del C., \& Samuel Sánchez, J. (2010). The school curriculum and environmental education: A school environmental audit experience. International Journal of Environmental and Science Education, 5(4), 477-494.

Daryanto, Suprihatin Agung. (2013). Pengantar Pendidikan Lingkungan Hidup. Yogyakarta:Gava Media, 24.

Hadzigeorgiou, Y., \& Skoumios, M. (2013). The development of environmental awareness through school science: Problems and possibilities. International Journal of Environmental and Science Education, 8(3), 405-426.

https://doi.org/10.12973/ijese.2013.212a

Hannah Rich, \& Nicole M. Ardoin. (2014). Teacher and Administrator Perceptions of School Gardens in Cape Town, South Africa. Children, Youth and Environments, $24(3), \quad 58$. https://doi.org/10.7721/chilyoutenvi.24.3.0058
Mardiana, D. (2014). Internalisasi Nilai Etika Lingkungan di Sekolah Dasar. Sosioreligi, VI(9), $1-10$.

Miles, M. B., \& Huberman, A. M. (1994). An analytic approach for discovery. In CEUR Workshop Proceedings (Vol. 1304).

Permana, B. I., \& Ulfatin, N. (2018). Budaya Sekolah Berwawasan Lingkungan. KAJIAN TEORI DAN PRAKTIK KEPENDIDIKAN, 3, 11-21.

Potter, J. F. (2015). Greening the curriculum. The Environmentalist, 12(3), 161-163. https://doi.org/10.1007/BF01267598

Suriansyah, A., \& Aslamiah. (2015). Strategi Kepemimpinan Kepala Sekolah, Guru, Orang Tua, Dan Masyarakat Dalam Membentuk Karakter Siswa. Jurnal Cakrawala Pendidikan, 2(2), https://doi.org/10.21831/cp.v2i2.4828

Treagust, D. F., Amarant, A., Chandrasegaran, A. L., \& Won, M. (2016). A case for enhancing environmental education programs in schools: Reflecting on primary school students' knowledge and attitudes. International Journal of Environmental and Science Education, 11(12), 5591-5612.

The Management Strategy of Headmaster in Efforts to Increase Self Awareness of School Residents of The Importance Environment| 67 